\title{
Exigências de proteína de animais Nelore puros e cruzados com as raças Angus e Simental ${ }^{1}$
}

\author{
Marcos Inácio Marcondes², Sebastião de Campos Valadares Filho ${ }^{3}$, Ivanna Moraes de \\ Oliveira $^{2}$, Rilene Ferreira Diniz Valadares ${ }^{4}$, Mário Fonseca Paulino ${ }^{3}$, Laura Franco Prados ${ }^{5}$
}

${ }^{1}$ Financiado pela Fundação de Amparo à Pesquisa de Minas Gerais (FAPEMIG)/Conselho Nacional de Pesquisa (CNPq).

2 Programa de pós-graduação em Zootecnia, Universidade Federal de Viçosa.

${ }^{3}$ Departamento de Zootecnia da Universidade Federal de Viçosa.

${ }^{4}$ Departamento de Medicina Veterinária da Universidade Federal de Viçosa.

${ }^{5}$ Curso de graduação em Zootecnia, Universidade Federal de Viçosa.

RESUMO - Objetivou-se estimar as exigências de proteína de animais Nelore, Nelore-Angus e Nelore-Simental, assim como a eficiência de uso da proteína metabolizável para ganho. Foram utilizados 69 animais (23 Nelore, 23 Nelore-Angus e 23 Nelore-Simental): 12 (quatro de cada grupo genético) foram abatidos antes do início do experimento, como grupo-referência, e nove animais foram separados para um ensaio de digestibilidade. Os animais restantes foram divididos em três dietas (ofertas de concentrado na base de 1 ou $2 \%$ do peso corporal à vontade e $1 \%$ do nível de mantença). Ao final do experimento, todos os animais foram abatidos e a composição corporal e o peso de corpo vazio (PCVZ) determinados. O consumo de proteína metabolizável $\left(\mathrm{CP}_{\text {met }}\right)$ foi estimado pela proteína microbiana verdadeira digestível média somada à proteína digestível nãodegradada no rúmen. As exigências líquidas de proteína para ganho foram estimadas pela proteína retida (PR) em função do ganho de PCVZ (GPCVZ) e da energia retida. As exigências de proteína metabolizável para mantença foram estimadas pelo $\mathrm{CP}_{\text {met }}$ em função do GMD e as exigências líquidas para mantença pela $\mathrm{PR}$ em função do $\mathrm{CP}_{\text {met }}$. $\mathrm{O}$ grupo genético influenciou apenas a relação entre os diferentes ganhos, mas não teve efeito sobre as exigências líquidas de proteína para ganho, que podem ser estimadas por meio do modelo $\mathrm{PR}=\mathrm{GPCVZ} \times(238,5-16,73 \times(\mathrm{ER} / \mathrm{GPCVZ}))$. Não há influência de grupo genético sobre as exigências líquidas e metabolizáveis de proteína para mantença, cujos valores são de 1,72 g/PCVZ 0,75 e 3,09g/PC,75, respectivamente. Também não há efeito de grupo genético na energia retida em forma de proteína, assim como na eficiência de uso da proteína metabolizável para ganho, que é de 37,5\%.

Palavras-chave: cruzamento industrial, eficiência de uso da proteína, exigências, proteína líquida, proteína metabolizável, terminação

\section{Protein requirements of Nellore cattle and Nellore crossbred with Angus and Simmental}

\begin{abstract}
The objective was to estimate the protein requirements of Nellore, Nellore $\times$ Angus and Nellore $\times$ Simmental cattle, as well as efficiency of metabolizable protein for gain. Sixty-nine animals (23 Nellore, 23 Nellore $\times$ Angus and 23 Nellore $\times$ Simmental) were used, with 12 animals (four of each genetic group) slaughtered before the beginning of the experiment as the baseline group, and nine split for the performance of digestibility trial. The remaining animals were divided in three diets (concentrate offer of 1 or $2 \%$ of body weight and maintenance). At the end of the experiment, all animals were slaughtered and their corporal composition and empty body weight (EBW) were determined. The metabolizable protein intake (MPI) was estimated by the mean digestible microbial protein summed to digestibile rumen undegradable protein. The net protein requirements were estimated as retained protein by the retained energy (RE) and empty body gain (EBG). The requirements of metabolizable protein for maintenance were estimated as the MPI as function of average daily gain, and the net requirements for maintenance as retained protein (RP) as a function of MPI. The genetic group influenced only the ratio among gains. There were no effects of genetic group on net protein requirements for gain, and the model RP $=\mathrm{EBW} \times(238.5-16.73 \times(\mathrm{RE} / \mathrm{EBG}))$ is recommended to estimate them. Genetic group did not affect net or metabolizable protein requirement for maintenance, and the values obtained were $1.72 \mathrm{~g} / \mathrm{EBW}^{0.75}$ and $3.09 \mathrm{~g} / \mathrm{BW}^{0.75}$, respectively. Also, there were no genetic group effects on retained energy as protein, nor in metabolizable protein efficiency for gain, which is $37.5 \%$.
\end{abstract}

Key Words: efficiency of protein utilization, finishing, industrial crossbreds, metabolizable protein, net protein, requirements 


\section{Introdução}

O suprimento de proteína bruta nas dietas é um dos fatores que mais oneram a criação de bovinos no Brasil. Apesar da grande quantidade, muitas fontes disponíveis têm seu uso reduzido devido à sazonalidade e ao alto custo. Por isso, a determinação correta das exigências diárias de proteína dos animais é de extrema importância para evitar o fornecimento excessivo ou inferior ao exigido pelos animais.

Atualmente, o sistema mais utilizado para estimar as exigências de proteína para animais de corte no Brasil é o NRC (1996), sistema americano que tem como base a utilização de animais de raças taurinas. Entretanto, a raça Nelore é a mais utilizada no País e, além de sua larga emancipação, é também bastante utilizada para cruzamentos industriais com raças européias, como Angus, Simental, Limousin, entre outras. Esse tipo de cruzamento permite a utilização de animais com alto potencial de desempenho e uma resistência ao clima e parasitas maior que raças europeias puras quando criadas em ambientes tropicais.

Dessa forma, objetivou-se neste trabalho comparar e estimar as exigências líquidas de proteína e proteína metabolizável de animais Nelore, Nelore-Angus e NeloreSimental, assim como a eficiência de uso da proteína metabolizável para ganho.

\section{Material e Métodos}

O trabalho foi realizado no Laboratório Animal da Universidade Federal de Viçosa e o experimento conduzido durante o período de maio a setembro de 2007. Foram utilizados 69 bovinos castrados de 18 meses: 23 Nelore com $306,6 \pm 27,0 \mathrm{~kg}$ de peso corporal; $23 \mathrm{~F}_{1}$ Nelore-Angus com $363,8 \pm 32,8$ kg; e $23 \mathrm{~F}_{1}$ Nelore-Simental com 367,2 $\pm 27,2 \mathrm{~kg}$.

Do total de animais, 12 animais (quatro de cada grupo genético) foram designados como grupo-referência e abatidos após o período de adaptação, 12 como grupo mantença e 9 (três de cada grupo genético) foram destinados a um ensaio de digestibilidade.

Os animais não-pertencentes ao grupo-referência foram divididos em três dietas ( 1 ou $2 \%$ do peso corporal em oferta de concentrado e grupo mantença) de forma inteiramente casualizada em esquema fatorial $3 \times 3$ (três dietas e três grupos genéticos) com seis repetições para os animais alimentados à vontade e quatro para os mantença.

Durante 30 dias, de 30 dias, todos os animais receberam foram submetidos a um período de adaptação, no qual receberam uma dieta composta por $55 \%$ de volumoso (silagem de milho) e $45 \%$ de concentrado à base de milho, farelo de soja, caroço de algodão, casca de soja, ureia e minerais (12,5\% PB). Após esse período, o grupo-referência foi abatido para determinação do peso de corpo vazio (PCVZ) dos animais remanescentes.

Após o abate do grupo-referência, aqueles animais que foram designados a receber $2 \%$ do peso corporal em concentrado passaram uma semana recebendo $1,5 \%$ do peso corporal (PC) em concentrado e mais uma semana recebendo $2 \%$ do $\mathrm{PC}$ em concentrado para adaptação à dieta. Os animais que foram designados a receber $1 \%$ do PC em concentrado iniciaram com sua dieta imediatamente após o abate do grupo referência.

Os animais em mantença também iniciaram seu tratamento após o abate do grupo-referência. Esses animais foram ofertados com 1,1\% do peso corporal (PC) em matéria seca e alimentados com a mesma dieta fornecida aos animais que receberam $1 \%$ do PC em concentrado, o que representou $40 \%$ da dieta em concentrado, na base da matéria seca.

Ao término dessa segunda semana, todos os animais foram pesados para início do primeiro período experimental. Esse período de adaptação à dieta foi chamado de segunda adaptação.

Os animais foram mantidos em baias individuais, com piso de concreto providas de comedouro e bebedouro de concreto, com área total de $30 \mathrm{~m}^{2}$, dos quais $8 \mathrm{~m}^{2}$ de área coberta com telhas de amianto. As rações foram formuladas para que as dietas fossem isoproteicas $(12,5 \%)$, sendo os consumos estimados segundo as Tabelas Brasileiras de Exigências Nutricionais de Zebuínos - BR-CORTE (Valadares Filho et al., 2006) e as exigências de macro e microminerais ajustadas de acordo com o NRC (1996).

Os concentrados foram formulados para que a mesma ração fosse ofertada para ambas dietas, mudando apenas a relação milho e ureia/sulfato de amônia, assim mantendo as dietas isoproteicas. O volumoso foi constituído de silagem de milho e os concentrados formulados à base de milho moído fino, farelo de soja, caroço de algodão, casca de soja, ureia/sulfato de amônio, bicarbonato de sódio, óxido de magnésio, sal comum e mistura mineral (Tabelas 1 e 2). Todas as dietas foram formuladas para conter um mínimo de $20 \%$ de fibra em detergente neutro.

Ao longo do experimento, a relação média volumoso:concentrado foi de 58,70:41,30 e 24,84:75,16 para as ofertas de 1 e $2 \%$ do PC, respectivamente.

O experimento teve duração total de 131 dias, sendo 30 dias de adaptação às condições experimentais, 14 dias de adaptação à dieta (segunda adaptação), três períodos de 28 dias, mais três dias para o abate dos animais. Após a segunda adaptação foi feita a avaliação no desempenho 
Tabela 1 - Composição química dos ingredientes utilizados na ração experimental

\begin{tabular}{|c|c|c|c|c|c|c|}
\hline Item & $\begin{array}{l}\text { Caroço de } \\
\text { algodão }\end{array}$ & $\begin{array}{l}\text { Casca } \\
\text { de soja }\end{array}$ & $\begin{array}{l}\text { Farelo } \\
\text { de soja }\end{array}$ & Milho & $\begin{array}{l}\text { Silagem } \\
\text { de milho }\end{array}$ & $\begin{array}{l}\text { Mistura } \\
\text { mineral }\end{array}$ \\
\hline Matéria seca (\%) & 91,18 & 88,68 & 88,61 & 88,38 & 28,95 & - \\
\hline Matéria orgânica (\% MS) & 96,91 & 96,19 & 94,04 & 98,97 & 93,32 & - \\
\hline Proteína insolúvel em detergente neutro/PB (\% da PB) & 12,79 & 40,10 & 11,68 & 29,72 & 19,55 & - \\
\hline Extrato etéreo (\% MS) & 15,75 & 1,05 & 1,48 & 3,36 & 2,44 & - \\
\hline Fibra em detergente neutro, FDN (\% MS) & 49,63 & 67,43 & 17,58 & 21,95 & 52,48 & - \\
\hline FDN indigestível (\% MS) & 20,47 & 6,32 & 2,60 & 3,07 & 19,60 & - \\
\hline FDA indigestível (\% MS) & 16,27 & 3,22 & 1,04 & 1,14 & 10,61 & - \\
\hline Fósforo (\% MS) & 0,94 & 0,20 & 1,02 & 0,50 & 0,36 & 15,57 \\
\hline Cálcio (\% MS) & 0,31 & 0,81 & 0,56 & 0,25 & 0,36 & 31,54 \\
\hline Magnésio (\% MS) & 0,29 & 0,27 & 0,35 & 0,11 & 0,11 & 0,66 \\
\hline Sódio (\% MS) & 0,16 & 0,17 & 0,11 & 0,11 & 0,14 & 0,23 \\
\hline
\end{tabular}

Tabela 2 - Proporção dos ingredientes nos concentrados e nas dietas, com base na matéria seca, e composição dos concentrados e dietas

\begin{tabular}{|c|c|c|c|c|}
\hline \multirow[t]{2}{*}{ Ingrediente } & \multicolumn{2}{|c|}{$1 \%$} & \multicolumn{2}{|c|}{$2 \%$} \\
\hline & Concentrado & Dieta & Concentrado & Dieta \\
\hline & \multicolumn{4}{|c|}{ Proporção } \\
\hline Caroço de algodão & 12,28 & 5,07 & 12,07 & 9,07 \\
\hline Casca de soja & 26,93 & 11,12 & 26,66 & 20,04 \\
\hline Ureia & 3,17 & 1,31 & 1,06 & 0,80 \\
\hline Farelo de soja & 2,02 & 0,84 & 2,09 & 1,57 \\
\hline Mistura mineral ${ }^{1}$ & 0,69 & 0,29 & 0,70 & 0,52 \\
\hline Cloreto de sódio & 0,69 & 0,29 & 0,70 & 0,52 \\
\hline Cloreto de potássio & 0,35 & 0,14 & 0,35 & 0,26 \\
\hline Óxido de magnésio & 0,32 & 0,13 & 0,32 & 0,24 \\
\hline Bicarbonato de sódio & 0,63 & 0,26 & 0,64 & 0,48 \\
\hline Proteína bruta (\%MS) & 20,69 & 12,73 & 14,96 & 13,02 \\
\hline Extrato etéreo (\%MS) & 4,01 & 3,09 & 4,06 & 3,66 \\
\hline Fibra em detergente neutro isenta de cinzas e proteína (\%MS) & 41,18 & 45,84 & 35,51 & 38,89 \\
\hline Carboidratos não-fibrosos (\%MS) & 52,39 & 41,96 & 48,21 & 44,83 \\
\hline Nutrientes digestível totais (\%MS) & - & 70,50 & - & 70,27 \\
\hline Energia digestível (Mcal/kg) & - & 3,11 & - & 3,10 \\
\hline Energia metabolizável (Mcal/kg) & - & 2,54 & - & 2,54 \\
\hline Fósforo (\%MS) & 0,56 & 0,44 & 0,57 & 0,52 \\
\hline Cálcio (\%MS) & 0,67 & 0,49 & 0,67 & 0,59 \\
\hline Magnésio (\%MS) & 0,35 & 0,21 & 0,36 & 0,30 \\
\hline Sódio (\%MS) & 0,55 & 0,31 & 0,55 & 0,45 \\
\hline Potássio (\%MS) & 0,95 & 1,14 & 0,96 & 1,04 \\
\hline
\end{tabular}

${ }^{1}$ Composição: cálcio - 24,0\%; fósforo - 17,4\%; cobalto - 100,0 ppm; cobre - 1.250,0 ppm; ferro - 1.795,0 ppm; manganês - 2.000,0 ppm; selênio - 15,0 ppm; zinco - 5.270,0 ppm; iodo - 90,0 ppm.

dos animais por um período de 74 dias, sendo duas pesagens intermediárias (ao final de 28 e 56 dias) realizadas para monitoramento do desempenho dos mesmos.

Os alimentos foram fornecidos duas vezes ao dia e ajustados de forma a manter as sobras em torno de 5 a $10 \%$ do fornecido, com água permanentemente à disposição dos animais. Como a quantidade fornecida de concentrado foi fixa, apenas a quantidade de volumoso foi ajustada diariamente, sendo que, para evitar problemas de acidose aguda, foi fixado um mínimo de 5 kg de matéria natural de silagem por dia.

Como densidade do caroço de algodão e da casca de soja possuem é diferente da dos outros ingredientes do concentrado, todos os dias estes foram pesados e 
adicionados à mistura contendo os outros ingredientes. No primeiro período, a oferta de concentrado foi corrigida semanalmente com base no desempenho dos animais na segunda adaptação e, no segundo e terceiro períodos, esse ajuste foi feito, também semanalmente, com base no desempenho dos períodos anteriores.

A dieta oferecida foi registrada diariamente, assim como foram coletadas amostras da silagem de milho, caroço de algodão, casca de soja e das sobras de cada animal. O milho, o farelo de soja e a mistura mineral foram amostrados diretamente dos silos da fábrica de ração nos dias das misturas.

As amostras de sobras e alimentos fornecidos foram agrupadas em amostras compostas semanais, proporcionais à matéria pré-seca, e foi determinada a matéria seca de todas essas subamostras para obtenção do consumo de matéria seca. A partir das amostras compostas semanais foi elaborada uma amostra composta por cada período de 28 dias, também proporcional à matéria pré-seca dos materiais. Nas amostras compostas de cada período foi determinada toda sua composição química.

A descrição detalhada das análises químicas é apresentada por Marcondes et al. (2011). Também é descrito naquele trabalho o ensaio realizado para determinação das digestibilidades dos nutrientes e do consumo de nutrientes digestíveis totais (NDT).

As amostras coletadas foram pré-secas em estufa ventilada a $65{ }^{\circ} \mathrm{C}$ por 72 horas e moídas em moinho com peneira de malha de $1 \mathrm{~mm}$ por 10 minutos, sendo o remanescente do moinho adicionado à amostra moída.

Marcondes et al. (2009b) descreveram como foi determinada a eficiência microbiana, estimada utilizando os derivados de purinas na urina, sendo adotado o valor médio de 120,36 g $\mathrm{P}_{\text {mic }} / \mathrm{kg}$ NDT, obtido para os animais deste experimento, não havendo efeitos de grupo genético ou dieta.

O consumo de proteína metabolizável foi calculado como o de proteína microbiana verdadeira digestível mais a proteína não degradável no rúmen digestível. A proteína microbiana foi calculada a partir do consumo de NDT, sendo sua fração verdadeira adotada como $80 \%$ e sua digestibilidade também adotada como 80\% (NRC, 2001). O consumo de proteína não degradada no rúmen foi estimado como o consumo de proteína bruta menos a produção de proteína microbiana, e sua digestibilidade considerada como $80 \%$.

Ao término do período de avaliação do desempenho, iniciou-se o abate dos animais, sendo abatidos seis animais por dia (um de cada raça e nível de concentrado) com um intervalo de um dia para dissecação das carcaças entre cada abate. Antes dos abates, os animais foram submetidos a jejum de sólidos de 16 horas. O abate foi realizado via insensibilização e secção da jugular para sangramento total, seguido de lavagem do aparelho gastrintestinal (rúmen, retículo, omaso, abomaso e intestinos delgado e grosso).

Os pesos do coração, pulmões, fígado, baço, rins, gordura interna, carne industrial, mesentério, cauda e aparas, juntamente com os do trato gastrintestinal lavado, foram somados aos das demais partes do corpo (carcaça, cabeça, couro, pés e sangue) para determinação do peso de corpo vazio (PCVZ).

A relação média obtida entre o PCVZ e o peso corporal do grupo referência foi utilizada para a estimativa do PCVZ inicial dos animais que permaneceram em alimentação. Após o abate, a carcaça de cada animal foi dividida em duas meiascarcaças, as quais foram pesadas para determinação do rendimento de carcaça quente e, em seguida, resfriadas em câmara a $4{ }^{\circ} \mathrm{C}$, durante 18 horas. Decorrido este tempo, as meias-carcaças foram retiradas da câmara fria e pesadas para determinação do rendimento de carcaça fria.

Todas as meias-carcaças direitas foram dissecadas em ossos, gordura e músculo, sendo que músculo e gordura foram moídos separados e posteriormente foi feita uma amostra composta proporcional à presença na carcaça de cada um desses tecidos. Já os ossos foram separados em ossos longos, vértebras e costelas, amostrados e serrados, sendo feita uma amostra composta de ossos da carcaça, também proporcional ao seu peso na carcaça.

O rúmen, retículo, omaso, abomaso, intestino delgado, intestino grosso, gordura interna, mesentério, fígado, coração, rins, pulmão, língua, baço, carne industrial e aparas (esôfago, traquéia e aparelho reprodutor), foram triturados em um cutter industrial por 20 minutos, constituindo uma amostra composta de vísceras e órgãos.

As amostras de sangue foram coletadas imediatamente após o abate (durante a sangria), acondicionadas em recipiente de vidro e levadas à estufa de ventilação forçada, a $65{ }^{\circ} \mathrm{C}$, durante 72 horas, para determinação do teor de (MS), sendo, a seguir, processadas em moinho de bola e acondicionadas em recipientes para posteriores análises de nitrogênio total e extrato etéreo, conforme Silva \& Queiroz (2002).

Aleatoriamente foram escolhidos dois animais de cada tratamento (dieta $\times$ grupo genético), que tiveram suas cabeças e pés amostrados. Esses foram dissecados em couro, tecido mole e ossos, sendo que o couro foi somado ao do corpo e descartado, o tecido mole moído e os ossos serrados para proceder a amostragem. A composição média da cabeça e pés desses animais para cada tratamento foi utilizada como base de cálculo da composição dos animais que não tiveram seus pés e cabeça amostrados. 
Com exceção do sangue, todas as amostras (órgãos+vísceras, músculo+gordura, ossos, tecido mole e couro) foram liofilizadas por 72 a 96 horas para determinação da material pré-seca gordurosa (MSG).

Posteriormente, as amostras foram submetidas a um pré-desengorduramento (MSPD) por extração por éter no aparelho Soxhlet por 6 h, em média. Em seguida, as amostras foram moídas em moinho de bola, para posteriores determinações de nitrogênio total e extrato etéreo, conforme Silva \& Queiroz (2002). A gordura removida no prédesengorduramento foi calculada pela diferença entre a MSG e a MSPD, cujo resultado foi adicionado aos obtidos para o extrato etéreo residual na MSPD, para determinação do teor total de gordura.

Os conteúdos corporais de gordura e proteína foram determinados em função das concentrações percentuais desses nos órgãos e vísceras, no couro, no sangue, na cabeça, nos pés e nas amostras da carcaça (ossos, músculo e gordura).

A determinação da energia corporal foi obtida a partir dos teores corporais de proteína e gordura e seus respectivos equivalentes calóricos de 5,6405 e 9,3929; conforme a equação preconizada pelo ARC (1980).

O conteúdo de proteína no corpo dos animais de cada tratamento, e para todos os tratamentos em conjunto, foi estimado por meio de equações não lineares dos conteúdos corporais de proteína dos animais em desempenho e referência, em função do PCVZ, conforme o seguinte modelo:

Proteína Corporal $(\mathrm{kg})=\mathrm{a} \times \mathrm{PCVZ}^{\mathrm{b}}$

onde, PCVZ é o peso de corpo vazio e 'a' e 'b’ são parâmetros da regressão.

A partir dos parâmetros da regressão acima apresentados, os requerimentos líquidos de proteína por quilo de ganho de peso de corpo vazio foram estimados pela derivada da equação acima, segundo o modelo:

$$
\mathrm{PL}_{\mathrm{g}}=\mathrm{a} \times \mathrm{b} \times \mathrm{PCVZ}^{\mathrm{b}-1} \times 1.000
$$

onde, $\mathrm{PL}_{\mathrm{g}}$ é o requerimento líquido de proteína para ganho (g/GPCVZ), PCVZ é o peso de corpo vazio e ‘a' e ‘b’ são parâmetros da regressão

Para cálculo dos requerimentos líquidos de proteína para ganho em qualquer faixa de desempenho foi ajustado um modelo de acordo com a energia retida retirando-se os animais mantidos em nível de mantença do modelo:

$$
\mathrm{PR}=\beta_{0}+\beta_{1} \times \mathrm{GMD}+\beta_{2} \times \mathrm{ER}
$$

em que: $\mathrm{PR}=$ proteína retida (g/dia); GMD = ganho médio diário em jejum (kg/dia); e ER = energia retida (Mcal/dia); $\beta_{0}$, $\beta_{1}$ e $\beta_{2}=$ parâmetros da regressão.

De forma alternativa, também foram calculadas essas exigências utilizando o ganho de peso de corpo vazio e a concentração de energia no ganho, também utilizando apenas os animais em desempenho:

$$
P R=G P C V Z \times\left(\beta_{1}+\beta_{2} \times \frac{E R}{G P C V Z}\right)
$$

em que: $\mathrm{PR}=$ proteína retida $(\mathrm{g} / \mathrm{dia}) ; \mathrm{GPCVZ}=$ ganho de peso de corpo vazio ( $\mathrm{kg} / \mathrm{dia}) ; \mathrm{ER}=$ energia retida (Mcal/dia); e $\beta_{1}$ e $\beta_{2}=$ parâmetros da regressão.

A proporção de energia retida na forma de proteína foi estimada segundo o modelo exponencial sugerido por Tedeschi et al. (2002). O $\hat{a}_{0}$ desse modelo representou a porcentagem mínima de participação da proteína na energia retida.

$$
R E_{P}=\beta_{0}+\beta_{1} \times e^{-\beta_{2} \times \frac{E R}{G P C V Z}}
$$

em que: REp = porcentagem de energia retida na forma de proteína; $\mathrm{ER}$ = energia retida; $\mathrm{GPCVZ}$ = ganho de peso de corpo vazio; $\beta_{0}$, $\beta_{1}$ e $\beta_{2}=$ parâmetros da regressão e 'e' é o número de Euller (3,718281).

Para cálculo dos requerimentos de proteína para mantença, foi adotado primeiramente o modelo sugerido pelo NRC (2000), onde o consumo de proteína metabolizável foi contrastado com o ganho médio diário para os animais em desempenho e mantença.

$$
\mathrm{CP}_{\text {met }}=\beta_{0}+\beta_{1} \times \mathrm{GMD}
$$

em que: $\mathrm{CP}_{\text {met }}=$ consumo de proteína metabolizável (g/dia); e GMD = ganho médio diário (kg/dia); $\beta_{0}$ e $\beta_{1}=$ parâmetros da regressão.

A divisão do intercepto dessa regressão pelo peso metabólico médio dos animais estimou os requerimentos de proteína metabolizável para mantença $\left(\beta_{0} \div P C_{\text {médio }}^{0,75}\right.$, $\left.\mathrm{g} / \mathrm{PC}^{0,75} / \mathrm{dia}\right)$.

De forma alternativa e utilizando o mesmo grupo de animais, a proteína retida foi plotada em função do consumo de proteína metabolizável.

$$
\mathrm{PR}=\beta_{0}+\beta_{1} \times \mathrm{CP}_{\text {met }}
$$

em que: $\mathrm{PR}=$ proteína retida $\left(\mathrm{g} / \mathrm{PCVZ}^{0,75} / \mathrm{dia}\right)$; e CPmet = consumo de proteína metabolizável (g/PCVZ ${ }^{0,75} /$ dia). O módulo do $\beta_{0}$ deste modelo representa os requerimentos líquidos de proteína para mantença e o $\beta_{1}$ a eficiência do uso de proteína metabolizável para ganho.

Os coeficientes $\beta_{0}$ e $\beta_{1}$ dos dois últimos modelos apresentados foram estimados pelo método da regressão ortogonal de Fuller (1987), que considera que ambas as variáveis do modelo possuem erros aleatórios associados a elas. Os parâmetros da equação foram obtidos da seguinte forma:

$$
\begin{aligned}
& \beta_{0}=\bar{Y}-\beta_{1} \times \bar{X} \\
& \beta_{1}=\frac{\sigma_{y}^{2}-\sigma_{x}^{2}+\sqrt{\left(\sigma_{y}^{2}-\sigma_{x}^{2}\right)^{2}+4 \times \sigma_{x y}^{2}}}{2 \times \sigma_{x y}^{2}}
\end{aligned}
$$

R. Bras. Zootec., v.40, n.10, p.2235-2243, 2011 
em que: $\bar{X}=$ média do da variável discriminante; $\bar{Y}=$ média da variável dependente; $\sigma^{2}{ }_{\mathrm{X}}=$ variância de $\mathrm{X} ; \sigma_{\mathrm{y}}^{2}=$ variância de $\mathrm{Y} ; \sigma_{\mathrm{xy}}=$ covariância entre X e Y.

Os modelos de conteúdo corporal de proteína e de retenção de energia na forma de proteína foram testados pelo teste de identidade de modelos de Regazzi \& Silva (2004). Já as regressões ortogonais e os modelos de cálculo de PCVZ e GPCVZ foram testadas pela indentidade de modelos de Regazzi (1999).

Os modelos de proteína retida em função do ganho médio diário e ganho de peso de corpo vazio mais energia mais energia retida foram testados pelo proc NLmixed do SAS (2008).

Para todos os testes, foi utilizado 5\% como nível crítico para identificar efeitos de grupo genético sobre os requerimentos de proteína dos animais.

\section{Resultados e Discussão}

Foram obtidas equações de conteúdo de proteína corporal para cada grupo genético, sendo que as mesmas foram:

Nelore: proteína corporal $(\mathrm{kg})=0,5196 \times \mathrm{PCVZ}^{0,8104}$

Nelore-Angus: proteína corporal $(\mathrm{kg})=0,3477 \times$ PCVZ 0,8785

Nelore-Simental: proteína corporal $(\mathrm{kg})=0,1725 \times$ PCVZ ${ }^{0,9964}$

em que: PCVZ = peso de corpo vazio.

O teste de identidade de modelos (Regazzi \& Silva, 2004) não identificou diferenças significativas $(P>0,05)$ entre os grupos raciais. Portanto, uma equação conjunta foi determinada para estimar o conteúdo de proteína corporal dos animais usados no experimento:

Proteína corporal $(\mathrm{kg})=0.3017 \times \mathrm{PCVZ}^{0,9028}$.

A partir da derivada desta equação foram estimadas as exigências líquidas de proteína para ganho (Tabela 3). Os dados mostraram menores valores numéricos de exigências apresentados pelos animais Nelore, mas não houve diferença entre os grupos genéticos.

Os valores encontrados pelo BR-CORTE são inferiores àqueles estimados nesse trabalho, mostrando que podem existir diferenças em exigências nutricionais de proteína entre animais zebuínos puros e cruzados, entretanto faltam trabalhos na literatura que comprovem essa hipótese.

Observou-se decréscimo nas exigências líquidas de proteína conforme o peso corporal aumentou, fato esperado, tendo em vista a queda na taxa de crescimento do animal quando o mesmo se aproxima da maturidade, com consequente mudança no metabolismo do animal no sentido de diminuir o fluxo de nutrientes para a deposição de tecido magro e aumentar as reservas corporais (Berg \& Butterfield, 1968).

Os dados indicaram também queda menos acentuada para os animais Nelore-Simental. De acordo com o NRC (1996), o Simental é um animal tardio, portanto essa ausência de queda nas exigências de proteína está relacionada desenvolvimento do animal, sendo sua maturidade atingida após os pesos corporais atingidos no experimento. Fato também foi evidenciando por Gourlart et al. (2008). Contudo, Véras et al. (2001) e Freitas et al. (2006) não encontraram diferenças significativas nas exigências líquidas de proteína de animais de diferentes grupos genéticos. Mostrando que há um necessidade de uma meta-análise com o dados da literatura para que se obtenha uma avaliação do efeito racial sobre esses requisitos.

Foram construídas equações para cálculo das exigências de proteína para qualquer faixa de desempenho, com base no desempenho e energia retida. Assim como o modelo mostrado anteriormente, foram construídas equações para cada grupo genético:

Nelore-Simental: PR =62,29+157,56 $\times$ GMD $-12,44 \times E R$

Nelore: $\mathrm{PR}=52,02+108,87 \times \mathrm{GMD}-6,43 \times \mathrm{ER}$

Nelore-Angus: $\mathrm{PR}=65,51+112,78 \times \mathrm{GMD}-3,80 \times \mathrm{ER}$ onde, PR é a proteína retida (g/dia), GMD é o ganho médio diário em jejum (kg/dia) e ER é a energia retida (Mcal/dia).

Não foi observado efeito de grupo genético sobre nenhum dos coeficientes do modelo acima descrito $(\mathrm{P}>0,05)$. $\mathrm{O}$ intercepto obtido foi maior e o coeficiente do GMD menor que a maioria daqueles observados na literatura (Paulino et al., 2009; Paulino et al., 2004; Véras et al., 2000), mostrando que parte da influência do ganho médio diário foi

Tabela 3 - Exigência líquida de proteína para ganho (g/kg de ganho de corpo vazio) de animais de diferentes grupos genéticos e em conjunto, em função de diferentes pesos corporais e por tabela (BR-CORTE)

\begin{tabular}{ccccc}
\hline Peso corporal & Nelore & Nelore-Angus & Nelore-Simental & Conjunta \\
\hline 250 & 150,26 & 157,82 & 168,55 & 160,60 \\
300 & 145,16 & 154,36 & 168,44 & 157,78 \\
350 & 140,97 & 151,50 & 168,34 & 155,43 \\
400 & 137,45 & 149,06 & 168,26 & 153,43 \\
450 & 134,41 & 146,94 & 168,19 & 151,68 \\
500 & 131,76 & 145,07 & 168,13 & 150,13 \\
550 & 129,40 & 143,40 & 168,07 & 130,97 \\
\end{tabular}


contabilizada no intercepto. Esse fato pode ter acontecido devido ao pequeno número de observações por grupo genético, uma vez que após agrupar todos os animais para a composição de uma equação conjunta esse efeito não aconteceu:

Equação conjunta: $\mathrm{PR}=10,41+134,87 \times \mathrm{GMD}-1,06 \times \mathrm{ER}$

É importante observar que não houve efeito significativo da variável energia retida sobre a proteína retida no corpo vazio dos animais, fato esse também observado por Veloso et al. (2002). No entanto, o mesmo foi mantido no modelo por esse ser utilizado na maioria dos trabalhos.

O NRC (2000) sugeriu outro modelo para estimar as exigências líquidas de proteína para ganho $(\mathrm{PR}=\mathrm{GMD} \times$ [268 - 29,4 × (ER/GMD)]), em que foi relacionado o ganho de proteína não só com a energia retida, mas com a proporção de energia no ganho. A partir dos dados obtidos nesse trabalho foram estimados os parâmetros de acordo com o modelo proposto pelo NRC (2000).

$$
\begin{aligned}
& \text { Nelore-Simental: } \mathrm{PR}=\mathrm{GMD} \times\left(170,2-5,11 \times \frac{\mathrm{ER}}{\mathrm{GMD}}\right) \\
& \text { Nelore: } \mathrm{PR}=\mathrm{GMD} \times\left(180,8-12,94 \times \frac{\mathrm{ER}}{\mathrm{GMD}}\right) \\
& \text { Nelore-Angus: } \mathrm{PR}=\mathrm{GMD} \times\left(146,9-1,17 \times \frac{\mathrm{ER}}{\mathrm{GMD}}\right)
\end{aligned}
$$

onde, PR é a proteína retida (g/dia), GMD é o ganho médio diário em jejum (kg/d) e ER é a energia retida (Mcal/dia).

Nesse modelo também não foi observado efeito de grupo genético, sendo estimado um modelo conjunto:

$$
\text { Equação conjunta: } \mathrm{PR}=\mathrm{GMD} \times\left(144,0-1,13 \times \frac{\mathrm{ER}}{\mathrm{GMD}}\right)
$$

Observou-se nos modelos propostos uma influência menor da concentração de energia retida no ganho para estimar a proteína retida do que no modelo proposto pelo NRC (2000). Talvez isso tenha ocorrido pelo fato do banco de dados do NRC (2000) possuir uma grande quantidade de animais mais pesados (com mais de $500 \mathrm{~kg}$ ), onde grande parte da energia retida é feita na forma de gordura, e não de proteína. No presente caso, a maior parte de ganho foi proporcionado por acréscimo de proteína, e não gordura, já que grande parte dos animais não atingiu mais que $25 \%$ de gordura corporal.

Chizzotti et al. (2008) utilizaram a mesma idéia do NRC (2000) em uma meta-análise de dados de experimentos conduzidos no Brasil com animais zebuínos puros e cruzados. Todavia os autores utilizaram o ganho de peso de corpo vazio, e não o ganho médio diário em jejum, como referência para estimar as exigências de proteína. O modelo apresentado pelos autores foi: $\mathrm{PR}=\mathrm{GPCVZ} \times(217-12,8 \times \mathrm{ER} / \mathrm{GPCVZ})$. Seguindo o modelo desses autores, foram estimadas as exigências líquidas de proteína para ganho, utilizando o GPCVZ.
Nelore-Simental: $\mathrm{PR}=\mathrm{GPCVZ} \times\left(263,59-17,63 \times \frac{\mathrm{ER}}{\mathrm{GPCVZ}}\right)$

Nelore: $\mathrm{PR}=\mathrm{GPCVZ} \times\left(140,73-0,70 \times \frac{\mathrm{ER}}{\mathrm{GPCVZ}}\right)$

Nelore-Angus: $\mathrm{PR}=\mathrm{GPCVZ} \times\left(243,48-19,01 \times \frac{\mathrm{ER}}{\mathrm{GPCVZ}}\right)$

Os coeficientes dos modelos de animais cruzados são bastante próximos aos sugeridos no modelo do NRC (2000), utilizando o ganho médio diário. Além disso, o modelo para animais Nelore dá suporte à discussão feita acima, onde animais mais leves e, portanto, ainda em fase de maior deposição de proteína, têm uma menor proporção de gordura no ganho de energia.

Entretanto, mais uma vez não foi evidenciado efeito de grupo genético sobre os coeficientes do modelo acima, sendo, dessa forma, estimado um modelo completo. Este é apresentado a seguir, e possui grande semelhança com o modelo proposto por Chizzotti et al. (2008):

Equação conjunta: $\mathrm{PR}=\mathrm{GPCVZ} \times\left(238,5-16,73 \times \frac{\mathrm{ER}}{\mathrm{GPCVZ}}\right)$

Para dar suporte aos dados apresentados até o momento, foi estimada a retenção de energia na forma de proteína como proposto por Tedeschi et al. (2002), onde a proporção de energia retida na forma de proteína é estimada a partir da concentração de energia no ganho. Foi verificado efeito de grupo genético sobre a retenção de energia na forma de proteína, entretanto apenas os animais Nelore-Angus se diferenciaram dos demais. Esses animais tiveram maior deposição de energia na forma de gordura que os outros grupos, mostrando que esses já se encontravam em fase mais avançada de maturidade.

Nelore e Nelore-Simental: $\mathrm{REp}=12,3961+66,8641 \times \mathrm{e}^{-0,4926 \times \frac{\mathrm{ER}}{\mathrm{CRCVZ}}}$ Nelore-Angus: $\operatorname{REp}=6,7208+293,2 \times \mathrm{e}^{-0,6855 \times \frac{\mathrm{ER}}{\operatorname{GPCV}}}$ em que REp proporção da energia retida na forma de proteína (\%).

Pode-se calcular, a partir dos modelos, que a porcentagem mínima de participação da proteína no ganho de energia é de $12,40 \%$ para animais Nelore e NeloreSimental e 6,72\% para Nelore-Angus. De acordo com o modelo proposto por Tedeschi et al. (2004), trabalhando com dados de animais taurinos, esse valor seria de 5,54\% e de acordo com Chizzotti et al. (2008), utilizando zebuínos puros e cruzados, a proporção de proteína no ganho de energia seria de 10,1\%. Dessa forma, observou-se que os animais Nelore-Angus encontravam em fase de maturidade mais avançada em relação aos demais e, de acordo com Geay (1984), a proporção de proteína no ganho cai linearmente com o aumento da deposição de energia.

Se for considerado um valor de concentração de energia retida no GPCVZ de 5,0 Mcal/GPCVZ, seria obtida uma proporção da proteína no ganho de 18,09\% para Nelore e 
Nelore-Simental e 16,24\% para Nelore-Angus. Utilizando-se as equações adotadas por Tedeschi et al. (2004) esse valor seria de $15,98 \%$ e segundo Chizzotti et al. (2008) seria de $16,25 \%$.

O conselho nacional de pesquisa dos EUA (NRC, 2000) adotou as exigências de proteína metabolizável para mantença de 3,8 g/kg PC $0,75 /$ dia. Esse valor foi encontrado por Wikerson et al. (1993), como o intercepto do consumo de proteína metabolizável (g/dia) em função do ganho médio diário (kg/dia), dividido pelo peso metabólico médio dos animais daqueles trabalhos.

Utilizando o mesmo modelo proposto pelo NRC (2000) foi possível estimar as exigências de proteína metabolizável para mantença (Figura 1). Não foi observado efeito de grupo genético sobre nenhum dos coeficientes do modelo, sendo, portanto, estimada uma equação conjunta para os três grupos avaliados.

Equação conjunta: $\mathrm{CP}_{\text {met }}=468,4183 \times \mathrm{GMD}+274,0977$, em que: $\mathrm{CP}_{\text {met }}=$ consumo de proteína metabolizável (g/dia); e GMD = ganho médio diário (kg/dia).

Dividindo o intercepto do modelo descrito para os dados em conjunto pelo peso metabólico médio dos animais (88,65 kg $\left.{ }^{0,75}\right)$, obteve-se exigência de 3,09 g/ $\mathrm{PC}^{0,75} / \mathrm{dia}$, valor abaixo daquele encontrado por Wikerson et al. (1993), porém próximo daquele preconizado pelo INRA (1988) de 3,25 g/PC ${ }^{0,75}$ e calculado por balanço de nitrogênio.

Outros métodos também são utilizados para estimar as exigências de proteína para mantença. Dentre eles, o método que tem sido mais utilizado é aquele que relaciona o nitrogênio retido com o nitrogênio consumido. Contudo, esse método tende a subestimar as exigências de proteína para mantença, pois não computa perdas de pêlos e descamação.

Plotando os dados de consumo de proteína metabolizável em função da proteína retida foram obtidas as

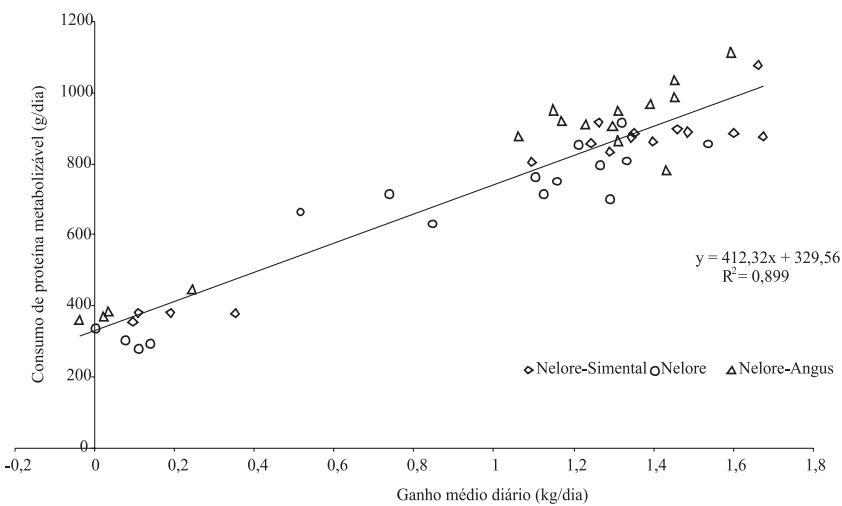

Figura 1 - Consumo de proteína metabolizável em função do ganho médio diário de três grupos genéticos. exigências líquidas de proteína para mantença, representadas pelo intercepto do modelo. A inclinação representa a eficiência de conversão de proteína metabolizável em proteína líquida para mantença (Figura 2).

Não foi observado efeito de grupo genético para nenhum dos coeficientes do modelo, sendo a proteína retida (PR) descrita em uma equação conjunta:

Equação conjunta: $\mathrm{PR}=0,3751 \times \mathrm{CP}_{\text {met }}-1.7168$ onde, $\mathrm{PR}$ é a proteína retida (g/PCVZ $\left.{ }^{0,75} / \mathrm{dia}\right)$ e $\mathrm{CP}_{\text {met }}$ é o consumo de proteína metabolizável (g/PCVZ ${ }^{0,75} /$ dia).

Pelo modelo, obteve-se exigência líquida de proteína para mantença de aproximadamente $1,72 \mathrm{~g} / \mathrm{PCVZ}^{0,75}$. Esse valor é menor que aqueles sugeridos pelo BR-CORTE (2006) e pelo AFRC (1993), de 2,69 e 2,30 g/PCVZ ${ }^{0,75}$, respectivamente, mas quase igual ao verificado por Chizzotti et al. (2008) para animais zebuínos puros e cruzados de $1,74 \mathrm{~g} / \mathrm{PCVZ}^{0,75}$. Entretanto, como já observado, os valores obtidos por essa técnica parecem subestimados.

Por outro lado, a eficiência de uso da proteína metabolizável para ganho foi de $37,51 \%$, sendo esse valor menor que o preconizado pelo NRC (2000) de 49,2\% para animais com peso corporal superior a $300 \mathrm{~kg}$.

De acordo com Oldham (1987), a eficiência de uso da proteína metabolizável é baseada no valor biológico da proteína e na eficiência de uso de uma "mistura ideal" de aminoácidos, sendo assim, fortemente influenciado pela qualidade da fonte de proteína não-degradada no rúmen e pelo valor biológico da proteína microbiana.

No presente trabalho, foram utilizadas fontes alternativas de alimentos como o caroço de algodão e a casca de soja, além da qualidade da silagem de milho feita no Brasil geralmente ser diferente daquela encontrada nos Estados Unidos. Dessa forma, é possível que esses fatores tenham contribuído para a menor eficiência de uso da proteína metabolizável.

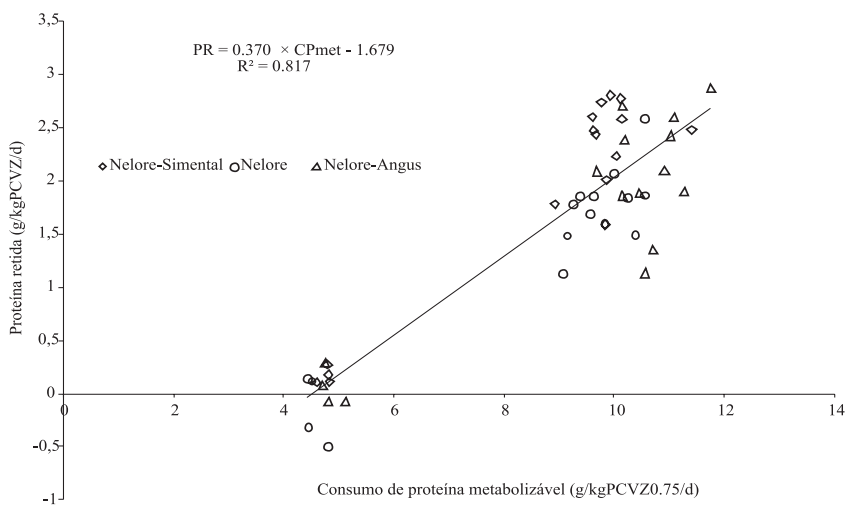

Figura 2 - Proteína retida em função do consumo de proteína metabolizável para os três grupos genéticos avaliados. 
Marcondes et al. (2009a), utilizando animais Nelore de três classes sexuais e alimentação à base de silagem de milho, milho moído e farelo de soja, encontraram uma eficiência de uso da proteina metabolizável para ganho de $50 \%$, semelhante à sugerida pelo NRC (2000), dando suporte às discussões feitas acima.

\section{Conclusões}

Sugere-se utilizar o modelo $\mathrm{PR}=\mathrm{GPCVZ} \times\left(238,5-16,73 \times \frac{\mathrm{ER}}{\mathrm{GPCVZ}}\right)$ para estimar as exigências de proteína e o valor 3,09 g/PC 0,75 as exigências de proteína metabolizável para mantença de bovinos zebuínos puros e cruzados.

\section{Referências}

AGRICULTURAL AND FOOD RESEARCH COUNCIL - AFRC. Energy and protein requirements of ruminants. Wallingford: Agricultural and Food Research Council; CAB International, 1993. 159p.

AGRICULTURAL RESEARCH COUNCIL - ARC. The nutrient requirements of ruminant livestock. London: Agricultural Research Council, The Gresham Press, 1980. 351p.

BERG, R.T.; BUTTERFIELD, R.M. Growth patterns of bovine muscle, fat and bone. Journal of Animal Science, v.27, n.3, p.611-679, 1968.

CHIZZOTTI, M.L.; TEDESCHI, L.O.; VALDARES FILHO, S.C. A meta-analysis of energy and protein requirements for maintenance and growth of Nellore cattle. Journal of Animal Science, v.86, n.7, p.1588-1597, 2008

FREITAS, J.A.; QUEIROZ, A.C.; DUTRA, A.R. et al. Eficiência de utilização da energia metabolizável em bovinos Nelore puros e cruzados submetidos a quatro níveis de concentrado na ração. Revista Brasileira de Zootecnia, v.35, n.3, p.894-901, 2006.

FULLER, W.A. Measurement error models. New York: John Wiley and Sons, 1987. 440p.

GEAY, Y. Energy and protein utilization in growing cattle. Journal of Animal Science, v.58, n.3, p.766-778, 1984.

GOULART, R.S.; ALENCAR, M.M.; POTT, E.B. et al. Composição corporal e exigências líquidas de proteína e energia de bovinos de quatro grupos genéticos terminados em confinamento. Revista Brasileira de Zootecnia, v.37, n.5, p.926-935, 2008.

INSTITUT NATIONAL DE LA RECHERCHE AGRONOMIQUE NRA. Alimentation des bovins, ovins et caprins. Besoins des animaux. Valeurs des aliments. Versailles: Editions Quae, 2007. 307p

MARCONDES, M.I.; VALADARES FILHO, S.C.; OLIVEIRA, I.M. et al. Eficiência alimentar de bovinos puros e cruzados recebendo alto ou baixo nível de concentrado. Revista Brasileira de Zootecnia, v.40, n.6, p.1313-1324, 2011.

MARCONDES, M.I.; VALADARES FILHO, S.C.; PAULINO, P.V.R. et al. Exigências nutricionais de proteína, energia e macrominerais de bovinos Nelore de três classes sexuais. Revista Brasileira de Zootecnia, v.38, n.8, p.1587-1596, 2009a.

MARCONDES, M.I.; VALADARES FILHO, S.C.; PRADOS, L.F. et al. Produção de proteína microbiana de animais Nelore puros e cruzados em dietas com alto ou baixo teor de concentrado ou em mantença. In: CONGRESSO NACIONAL DE ZOOTECNIA, 19., 2009, Águas de Lindóia. Anais... Pirassununga: Universidade de São Paulo, 2009b. (CD-ROM).
NATIONAL RESEARCH COUNCIL - NRC. Nutrient requirements of beef cattle. 7.ed. Washington, DC: National Academy Press, 1996. 242p.

NATIONAL RESEARCH COUNCIL - NRC. Nutrient requirements of beef cattle. updated 7.ed. Washington, DC: National Academy Press, 2000. 242p.

NATIONAL RESEARCH COUNCIL - NRC. Nutrient requirements of dairy cattle. 7.ed. Washington, DC: National Academy Press, 2001. 362p.

OLDHAM, J.D. Efficiencies of amino acid utilization. In: JARRIGE, R.; ALDERMAN, G. (Eds.) Feed evaluation and protein requirement systems for ruminants. Brussels: Commission of the European Communities, 1987. p.171-186.

PAULINO, P.V.R.; VALADARES FILHO, S.C.; DETMANN, E. et al. Deposição de tecidos e componentes químicos corporais em bovinos Nelore de diferentes classes sexuais. Revista Brasileira de Zootecnia, v.38, n.12, p.2516-2524, 2009.

PAULINO, P.V.R.; COSTA, M.A.L.; VALADARES FILHO, S.C.V. et al. Exigências nutricionais de zebuínos: proteína. Revista Brasileira de Zootecnia, v.33, n.3, p.759-769, 2004.

REGAZZI, A.J. Teste para verificar a identidade de modelos de regressão e a igualdade de parâmetros no caso de dados de delineamentos experimentais. Revista Ceres, v.46, n.266, p.383-409, 1999.

REGAZZI, A.J.; SILVA, C.H.O. Testes para verificar a igualdade de parâmetros e a identidade de modelos de regressão não-linear. I. Dados no delineamento inteiramente causalizado. Revista de Matemática e Estatística, v.22, n.3, p.33-45, 2004.

SILVA, D.J.; QUEIROZ, A.C. Análise de alimentos (métodos químicos e biológicos). 3.ed. Viçosa, MG: Imprensa Universitária, Universidade Federal de Viçosa, 2002. 165p.

STATISTICAL ANALYSES SYSTEM - SAS. SAS/STAT(r) 9.2 User's guide. Cary: SAS Institute Inc., 2008. 7857p.

STATISTICAL ANALYSES SYSTEM - SAS. Base SAS(r) 9.2 Procedures guide. Cary: SAS Institute Inc., 2008. 1598p.

TEDESCHI, L.O.; BOIN, C.; FOX, D.G. et al. Energy requirement for maintenance and growth of Nellore bulls and steers fed high-forage diets. Journal of Animal Science, v.80, p.1671-1682, 2002.

TEDESCHI, L.O.; FOX, D.G.; GUIROY, P.J. A decision support system to improve individual cattle management. 1. A mechanistic, dynamic model for animal growth. Agricultural Systems, v.79, p.171-204, 2004.

VALADARES FILHO, S.C.; PAULINO, P.V.R.; MAGALHÃES, K.A. Exigências nutricionais de zebuínos e tabelas de composição de alimentos - BR CORTE. Viçosa, MG: UFV, Suprema Gráfica Ltda, 2006. 142p.

VELOSO, C.M.; VALADARES FILHO, S.C.; GESUALDI JUNIOR, A. et al. Composição corporal e exigências energéticas e proteicas de bovinos F1 Limousin x Nelore, não-castrados, alimentados com rações contendo diferentes níveis de concentrado. Revista Brasileira de Zootecnia, v.31, n.3, p.1273-1285, 2002.

VÉRAS A.S.C.; VALADARES FILHO, S.C.; SILVA, J.F.C. et al. Composição corporal e requisitos energéticos e protéicos de bovinos Nelore, não-castrados, alimentados com rações contendo diferentes níveis de concentrado. Revista Brasileira de Zootecnia, v.29, n.6, p.2379-2389, 2000 (supl. 2).

VÉRAS, A.S.C.; VALADARES FILHO, S.C.; SILVA, J.F.C. et al. Predição da composição corporal e requisitos de energia e proteína para ganho de peso de bovinos, não-castrados, alimentados com rações contendo diferentes níveis de concentrado. Revista Brasileira de Zootecnia, v.30, n.3, p.1127-1134, 2001 (supl.).

WILKERSON, V.A.; KLOPFENSTEIN, T.J.; BRITTON, R.A. et al. Metabolizable protein and amino acid requirements of growing beef cattle. Journal of Animal Science, v.71, n.10, p.2777-2784, 1993. 